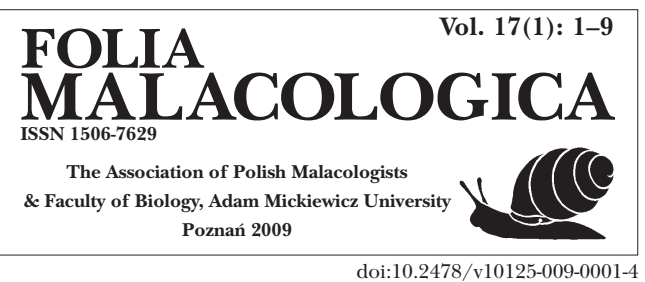

\title{
MOLECULAR PHYLOGENY AND ESTIMATED TIME OF DIVERGENCE IN THE CENTRAL EUROPEAN MELANOPSIDAE: MELANOPSIS, FAGOTIA AND HOLANDRIANA (MOLLUSCA: GASTROPODA: CERITHIOIDEA)
}

\author{
MARCIN SMOLEŃ, ANDRZEJ FALNIOWSKI
}

\begin{abstract}
Department of Malacology, Institute of Zoology, Jagiellonian University, Ingardena 6, 30-060 Kraków, Poland (e-mail: faln@zuk.iz.uj.edu.pl)

ABSTRACT: Three European melanopsids: Melanopsis parreyssii (Philippi, 1847) from Ochiul Mare (Romania), Fagotia acicularis (A. Férussac, 1828) from a spring near Crisul Negru (Romania), and Holandriana holandri (C. Pfeiffer, 1828) from Lake Skutari (Montenegro), as well as Melanopsis costata Oliver, 1804 from Iraq, are considered is this paper. Eight partial sequences of ribosomal 18S, and seven of mitochondrial COI were analysed. Maximum likelihood trees based on 18S confirm the placement of the Melanopsidae within the Cerithioidea, as well as the monophyly of the latter group. The COI-based tree confirms the placement of the Melanopsidae within the Cerithioidea, but does not confirm the monophyly of either Melanopsidae or Cerithioidea. The results suggest that Fagotia should be synonymised with Melanopsis, Holandriana is a distinct genus, and Melanopsis costata is not congeneric with $M$. parreyssii. The application of molecular clock, with one point calibration for COI for the Hydrobiidae, estimated the times of divergence as $2.53 \pm 0.56$ Mya for M. parreyssii and

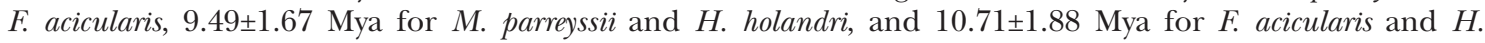
holandrii. 2.5 Mya coincides with the beginning of the glacial period in Europe, and 8-12 Mya was the time when Lake Pannon covered the largest area.
\end{abstract}

KEY WORDS: Melanopsidae, mtDNA, 18S, phylogeny, molecular clock, Lake Pannon

\section{INTRODUCTION}

The freshwater gastropod family Melanopside is world-wide distributed and rich in species. The phylogenetic relationships within the group and the position of the Melanopsidae are only fragmentarily known. The same concerns the species-level taxonomy, which is unclear (e.g. FALNIOWSKI et al. 2002a, b). This is due to the lack of taxonomically useful characters in their soft-part anatomy (e.g. they are aphallic) and the shell, which, like in most gastropods, is variable. Many authors agreed as to their placement within the Cerithioidea (e.g. THIELE 1929, HOUBRICK 1988, PONDER \& WARÉN 1988, HodgSON \& HELlER 1997, BIELER 1998), but recently LYDEARD et al. (2002), in their study on the $16 \mathrm{~S}$ mitochondrial sequences, did not confirm the monophyly of the Melanopsidae. This is not surprising: the Cerithioidea may have invaded freshwaters more than once. Many examples of the melanopsid radiation in ancient lakes are known, but there are few Recent species of this family in the European malacofauna. However, they dominated in Lake Pannon which covered a considerable part of Central Europe in the late Miocene-Pliocene, 12-4 Mya (GEARY et al. 2000, HARZHAUSER \& MANDIC 2008). The Recent melanopsid fauna in this part of Europe is most probably a relic of this radiation.

We have applied partial sequences of $18 \mathrm{~S}$ ribosomal DNA and COI mitochondrial DNA. The aims were as follows: 1. to check the position and monophyly of the Melanopsidae; 2. to infer the relationships between the three Central European genera: Melanopsis Férussac, 1807, Fagotia Bourguignat, 1884, and Holandriana Bourguignat, 1884; 3. to estimate, 
applying the molecular clock, the time of divergence between the genera, and try to relate it to the geological history of this part of Europe.

\section{MATERIAL AND METHODS}

\section{LOCALITY DESCRIPTION AND SNAIL COLLECTION}

Three European species of the Melanopsidae: Melanopsis parreyssii (Philippi, 1847), Fagotia acicularis (A. Férussac, 1828), and Holandriana holandri (C. Pfeiffer, 1828), as well as Melanopsis costata Olivier, 1804 from Iraq were used:

Melanopsis parreyssii - thermal spring, in the form of a small lake called Ochiul Mare in Băile 1 Mai (Băile Episcopiei) near Oradea, Romania; $46^{\circ} 59^{\prime} 54.2^{\prime \prime} \mathrm{N}$; $22^{\circ} 00^{\prime} 11.5^{\prime \prime} \mathrm{E}$; snails collected from a stony and gravelly substratum, among macrophytes, at a depth of ca. $0.3 \mathrm{~m}$;

Fagotia acicularis - big, tributary spring of the river Crisul Negru, between Giuta and Câpâlua, North of Ceika, South of Oradea, Romania; $46^{\circ} 45^{\prime} 3.6^{\prime \prime N}$; $22^{\circ} 12^{\prime} 48^{\prime \prime} \mathrm{E}$; snails collected from a sandy bottom, covered with a layer of detritus;

Holandriana holandri - Dolni Murići, the southern bank of Lake Skutari, Montenegro; $42^{\circ} 09^{\prime} 45^{\prime \prime} \mathrm{N}$, $19^{\circ} 13^{\prime} 21$ "E; snails collected from a sandy-stony bottom close to the shore.

For the phylogenetic inferences we used all the sequences representing the Cerithioidea, which were available from GenBank (Table 1), together with sequences of Aperostoma palmeri (Bartsch et Morrison, 1942), Bithynia tentaculata (Linnaeus, 1758), Bolinus brandaris (Linnaeus, 1758), Campanile symbolicum (Iredale, 1917), Crepidula adunca (Sowerby, 1825), Lithoglyphus naticoides (Pfeiffer, 1828), Bythinella austriaca (Frauenfeld, 1856), Rissoa labiosa (Montagu, 1803), and Littorina littorea (Linnaeus, 1758) as a multiple outgroup. To test the molecular clock, all the studied melanopsid taxa were used, the outgroups being the hydrobiids Peringia ulvae (Pennant, 1777) and Salenthydrobia ferrerii Wilke, 2003 whose divergence time was used to calibrate the clock.

Snails were collected with a sieve, or by hand. Their subsequent treatment with alcohol $(80 \%)$ was as follows. Firstly, they were washed twice and left to stand for ca. 12 hours. Afterwards, the alcohol was replaced and left to stand for another 24 hours, after which it was again replaced. Finally, after a few days, the $80 \%$ solution was exchanged for a $96 \%$ one; the material was stored at $-20^{\circ} \mathrm{C}$.

\section{MOLECULAR WORK}

Ethanol-fixed snails were washed three times with ice-cold water, than DNA was isolated according to the method described by Spolsky (SPOLSKY et al. 1996) and Davis (DAVIS et al. 1998) with modifications. The isolated DNA was used as a template in PCR reaction with the primers: LCO1490 (5'-GGTCAACAAA TCATAAAGATATTGG-3') and COR722b (5'-TAAACTTCAGGGTGACCAAAAAATYA-3') for CO1 gene (FOLMER et al. 1994, DAVIS et al. 1998) and SWAM18SF1 (5'-GAATGGCTCATTAAATCAGT CGAGGTTCCTTAGATGATCCAAATC-3'), and SWAM18SR1 (5'-ATCCTCGTTAAAGGGTTTAAA GTGTACTCATTCCAATTACGGAGC-3') for $18 \mathrm{~S}$ gene (PALUMBi 1996). The PCR conditions were: 1. For $\mathrm{CO} 1-4 \mathrm{~min}$. at $94^{\circ} \mathrm{C}$ followed by 35 cycles of 1 min. at $94^{\circ} \mathrm{C}, 1 \mathrm{~min}$. at $55^{\circ} \mathrm{C} 2 \mathrm{~min}$. at $72^{\circ} \mathrm{C}$, after all cycles an additional elongation step of $4 \mathrm{~min}$. at $72^{\circ} \mathrm{C}$ was performed; 2. For $18 \mathrm{~S}-4 \mathrm{~min}$. at $94^{\circ} \mathrm{C}$ followed by 40 cycles of $45 \mathrm{sec}$. at $94^{\circ} \mathrm{C}, 45 \mathrm{~b} \mathrm{sec}$. at $51^{\circ} \mathrm{C} 2 \mathrm{~min}$. at $72^{\circ} \mathrm{C}$, after all cycles an additional elongation step of $4 \mathrm{~min}$. at $72^{\circ} \mathrm{C}$ was performed. The PCR was made in $50 \mathrm{ml}$ volume, $10 \mathrm{ml}$ of which was electrophoresed in $1 \%$ agarose gel. After amplification the PCR product was purified using Clean-Up columns (A\&A Biotechnology) following the manufacturer's protocol. The purified PCR product was sequenced using the BigDye Terminator v. 3.1 (Applied Biosystems) following the manufacturer's protocol and with the same primers as for the PCR. The reaction product was purified using ExTerminator Columns (A\&A Biotechnology) following the manufacturer's protocol, and the sequences were read at an ABI Prism sequencer.

\section{DATA ANALYSIS}

The COI sequences were aligned by eye, using BioEdit 5.0.0 (HALL 1999) and edited with MACCLADE 4.05 (MADDISON \& MADDISON 2002). For 18S an initial alignment was performed using the CLUSTALX 1.82 (THOMPSON et al. 1997). Variable fragments that could not be aligned unambiguously were then removed with MACCLADE.

The maximum likelihood approach often tends to find the wrong reconstructions (NEI et al. 1998, NEI \& KUMAR 2000). There is no parameter associated with the tree topology in the entire maximum likelihood theory: one must simply assume that the tree with the "truest" branch lengths is also the one with the best topology (YANG et al. 1995, NEI 1987, 1996). There is also strong evidence that the more complicated the model of evolution, the higher the variance of the resulting reconstructions (NEI \& KUMAR 2000). Our knowledge of the evolution of DNA is still incom- 
plete, thus all the available models are rather unrealistic. It may happen that the simplest models will result in phylogeny reconstructions which are closest to the real historical processes (GAUT \& LEWIS 1995, YANG 1997, TAKAHASHI \& NEI 2000, FALNIOWSKI 2003). On the other hand, similar remarks can be made about other phylogenetic techniques as well, and the ML approach is not sensitive to the violation of some of its assumptions (SWOFFORD et al. 1996). Thus we decided to apply the maximum likelihood approach as implemented in PAUP*4.0b10 (SWOFFORD 2002). PAUP together with Modeltest (POSADA \& CRANDALL 1998) was used to find the appropriate model of evo- lution, with the Akaike Information Criterion (POSADA \& BUCKLEY 2004). This model was also selected for the set of taxa with Peringia and Salenhydrobia as an outgroup, and the best ML (branch-and-bound) trees were found to perform the Likelihood Ratio Test (LRT) (NEI \& KUMAR 2000, POSADA 2003) with PAUP. MEGA4 (TAMURA et al. 2007) was used to run the Relative Rate Tests (RRT) (TAJIMA 1993). The pairwise Maximum Composite Likelihood distances $(\stackrel{\mathrm{A}}{)})$ with standard errors $(10,000$ bootstrap replicates) were calculated with MEGA4. WILKE's (2003) data were used to calibrate the clock.

\section{RESULTS}

For the 18S, eight sequences, $444 \mathrm{bp}$ each, and for COI seven sequences, $663 \mathrm{bp}$ each, were analysed (Table 1).
For the $18 \mathrm{~S}$ the Akaike Information Criterion (AIC) with ModelTest found the model $\mathrm{K} 80+\mathrm{I}+\mathrm{G}$, with equal base frequencies, $\mathrm{Ti} / \mathrm{tv}$ ratio $=0.88891190$,

Table 1. Sequences used for phylogeny inference and molecular clock calibration

\begin{tabular}{|c|c|c|c|c|}
\hline \multirow[b]{2}{*}{ Species } & $18 \mathrm{~S}$ GB & \multirow[b]{2}{*}{ References } & CO1 GB & \multirow[b]{2}{*}{ References } \\
\hline & $\begin{array}{l}\text { accession } \\
\text { no }\end{array}$ & & $\begin{array}{l}\text { accession } \\
\text { no }\end{array}$ & \\
\hline Aperostoma palmeri (Bartsch and Morrison, 1942) & DQ093435 & GIRIBET et al. (2006) & DQ093523 & GIRIBET et al. (2006) \\
\hline Batillaria minima (Gmelin, 1791) & AF055649 & HARASEWYCH et al. (1998) & - & - \\
\hline Batillaria attramentaria (Sowerby, 1844) & - & - & DQ366385 & MIURA et al. (2006) \\
\hline Bithynia tentaculata (Linnaeus, 1758) & AF367675 & WILKE et al. (2001) & AF445334 & HAUSDORF et al. (2003) \\
\hline Bolinus brandaris (Linnaeus, 1758) & DQ279944 & GIRIBET et al. (2006) & $\mathrm{DQ} 280020$ & GIRIBET et al. (2006) \\
\hline Bythinella austriaca (Frauenfeld, 1856) & AF212917 & SZAROWSKA (2006) & $\mathrm{EF} 070617$ & SZAROWSKA (2006) \\
\hline Campanile symbolicum (Iredale, 1917) & DQ916524 & COLGAN et al. (2007) & AY296828 & COLGAN et al. (2003) \\
\hline Cerithium atratum (Born, 1778) & L78895 & HARASEWYCH et al. (1997) & L78907 & HARASEWYCH et al. (1997) \\
\hline Crepidula adunca (Sowerby, 1825) & X94277 & $\begin{array}{l}\text { WINNEPENNINCKX et al. } \\
\text { (1998) }\end{array}$ & AF546047 & COLLIN (2003) \\
\hline Lithoglyphus naticoides (Pfeiffer, 1828) & AF367674 & WILKE et al. (2001) & AF367642 & WILKE et al. (2001) \\
\hline Littorina littorea (Linnaeus, 1758) & DQ093437 & GIRIBET et al. (2006) & AJ622946 & WILLIAMS \& REID (2004) \\
\hline Maoriculpus roseus (Quoy and Gamard, 1834) & DQ916523 & COLGAN et al.(2007) & DQ916497 & COLGAN et al. (2007) \\
\hline Modulus modulus (Linnaeus, 1758) & AF055650 & HARASEWYCH et al. (1998) & - & - \\
\hline Rissoa labiosa (Montagu, 1803) & AY676126 & SZAROWSKA et al. (2005) & AY676128 & SZAROWSKA et al. (2005) \\
\hline Zeacumantus subcarinatus (Sowerby, 1855) & DQ916522 & COLGAN et al. (2007) & AY296834 & COLGAN et al. (2003) \\
\hline Salenthydrobia ferrerii Wilke, 2003 & - & - & AF449200 & WILKE 2003 \\
\hline Peringia ulvae (Pennant, 1777) & - & - & AF118288 & WILKE 2003 \\
\hline Melanopsis parreyssii (Philippi, 1847) 1 & FJ652192 & present study & FJ652185 & present study \\
\hline Melanopsis parreyssii (Philippi, 1847) 2 & FJ652193 & present study & FJ652186 & present study \\
\hline Melanopsis costata Olivier, 18041 & FJ652194 & present study & FJ652191 & present study \\
\hline Melanopsis costata Olivier, 18042 & FJ652195 & present study & - & - \\
\hline Fagotia acicularis (A. Férussac, 1828) 1 & FJ652196 & present study & FJ652187 & present study \\
\hline Fagotia acicularis (A. Férussac, 1828) 2 & FJ652197 & present study & FJ652188 & present study \\
\hline Holandriana holandri (C. Pfeiffer, 1828) 1 & FJ652198 & present study & FJ652189 & present study \\
\hline Holandriana holandri (C. Pfeiffer, 1828) 2 & FJ652199 & present study & FJ652190 & present study \\
\hline
\end{tabular}


proportion of invariable sites: $(\mathrm{I})=0.7941$, and Ă distribution with the shape parameter $=0.5421$. For the COI for all the taxa the Akaike Information Criterion (AIC) with ModelTest found the model $\operatorname{TrN}+\mathrm{I}+\mathrm{G}$, the base frequencies: $\mathrm{A}=0.3182, \mathrm{C}=0.1362, \mathrm{G}=0.1455$, $\mathrm{T}=0.4001$; substitution rate matrix: $[\mathrm{A}-\mathrm{C}]=1.0000$, $[\mathrm{A}-\mathrm{G}]=9.0122,[\mathrm{~A}-\mathrm{T}]=1.0000,[\mathrm{C}-\mathrm{G}]=1.0000,[\mathrm{C}-\mathrm{T}]$ $=22.8519,[\mathrm{G}-\mathrm{T}]=1.0000 ;$ proportion of invariable sites: $(\mathrm{I})=0.3987$, and $\mathrm{A}$ distribution with the shape parameter $=0.3434$.

The 18 S tree (Fig. 1) confirmed the monophyly of the Cerithioidea (bootstrap support 65), and Melanopsidae (bootstrap support 72). Melanopsis parreyssii was different from the other Melanopsidae. The COI tree (Fig. 2) confirmed the monophyly of neither the Cerithioidea nor the Melanopsidae. Melanopsis parreyssii and Fagotia acicularis were very close to each other (see also the distances: Table 2), forming the clade with support 88, but Holandriana holandri was distantly related to this clade. Melanopsis costata was the most distant from the other melanopsid species.
The K2P distances (KIMURA 1980), commonly used for interspecific comparisons (Table 2), averaged $0.0529 \pm 0.0029$ between Melanopsis parreyssii and Fagotia acicularis; $0.2044 \pm 0.0025$ between $M$. parreyssii and Holandriana holandri; $0.2040 \pm 0.0008$ between $F$. acicularis and $H$. holandri; 0.1499 between $M$. costata and $F$. acicularis; 0.2051 between $M$. costata and $H$. holandri; 0.1607 between M. costata and M. parreyssii. The mean distance between Holandriana holandri and the other, non-melanopsid species of the Cerithioidea was $0.2355 \pm 0.01722$.

For the COI, for the Melanopsidae with Salenthydrobia ferrerii and Peringia ulvae as outgroup the Akaike Information Criterion (AIC) with ModelTest found the model K81uf+I, the base frequencies: $\mathrm{A}=0.2733$, $\mathrm{C}=0.1710, \mathrm{G}=0.1727, \mathrm{~T}=0.3831$; substitution rate matrix: $[\mathrm{A}-\mathrm{C}]=1.0000,[\mathrm{~A}-\mathrm{G}]=23.7601,[\mathrm{~A}-\mathrm{T}]=$ 3.1399, $[\mathrm{C}-\mathrm{G}]=0.6448,[\mathrm{C}-\mathrm{T}]=23.7601,[\mathrm{G}-\mathrm{T}]=$ 1.0000 ; the proportion of invariable sites: $(\mathrm{I})=$ 0.6448 , and equal rates for all sites. The branch-and-bound ML tree computed for all the Melanopsidae with Salenthydrobia ferrerii and Peringia

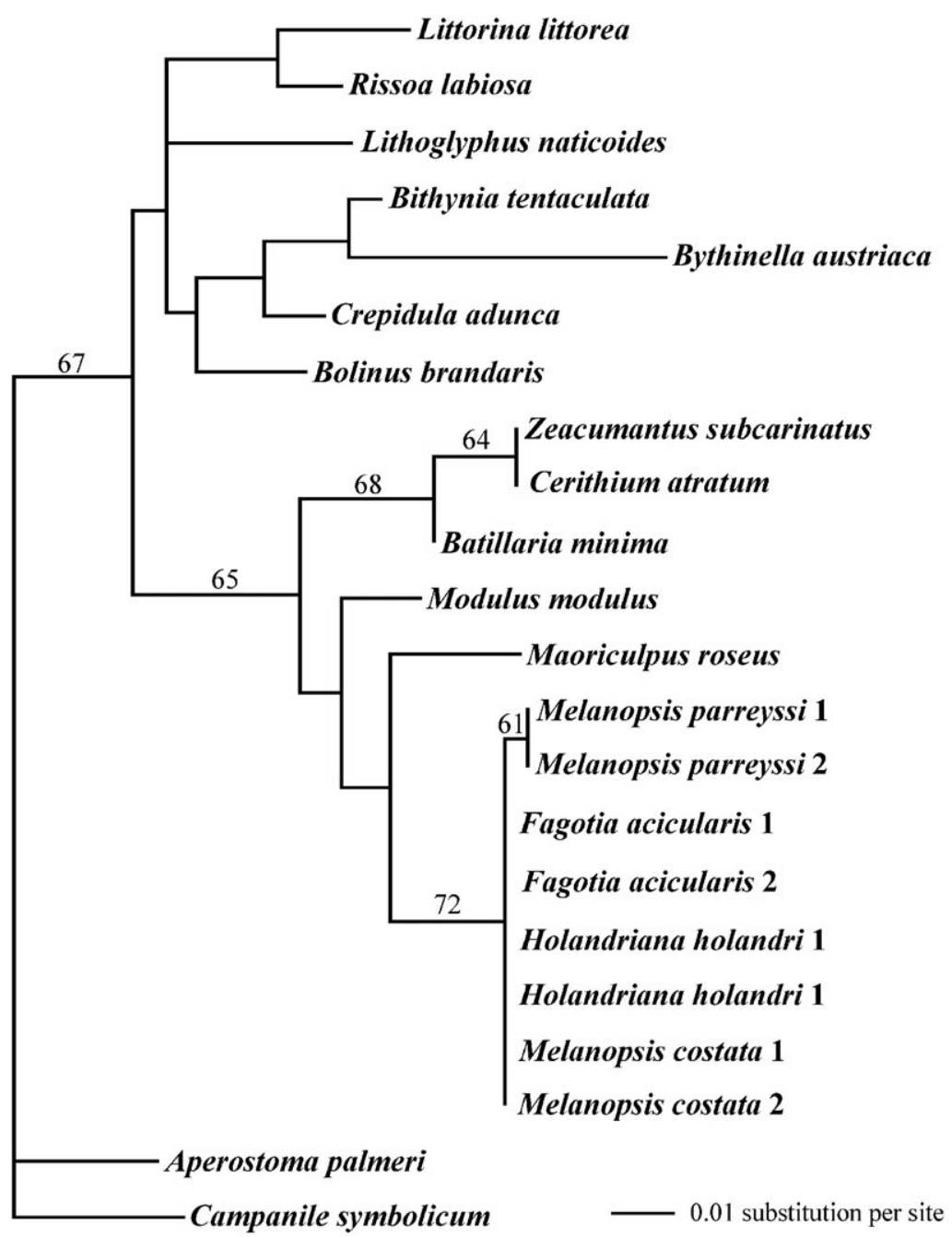

Fig. 1. Maximum likelihood phylogram for $18 \mathrm{~S}$ (see text for details). Bootstrap support indicated (10,000 replicates) when $>50 \%$ 


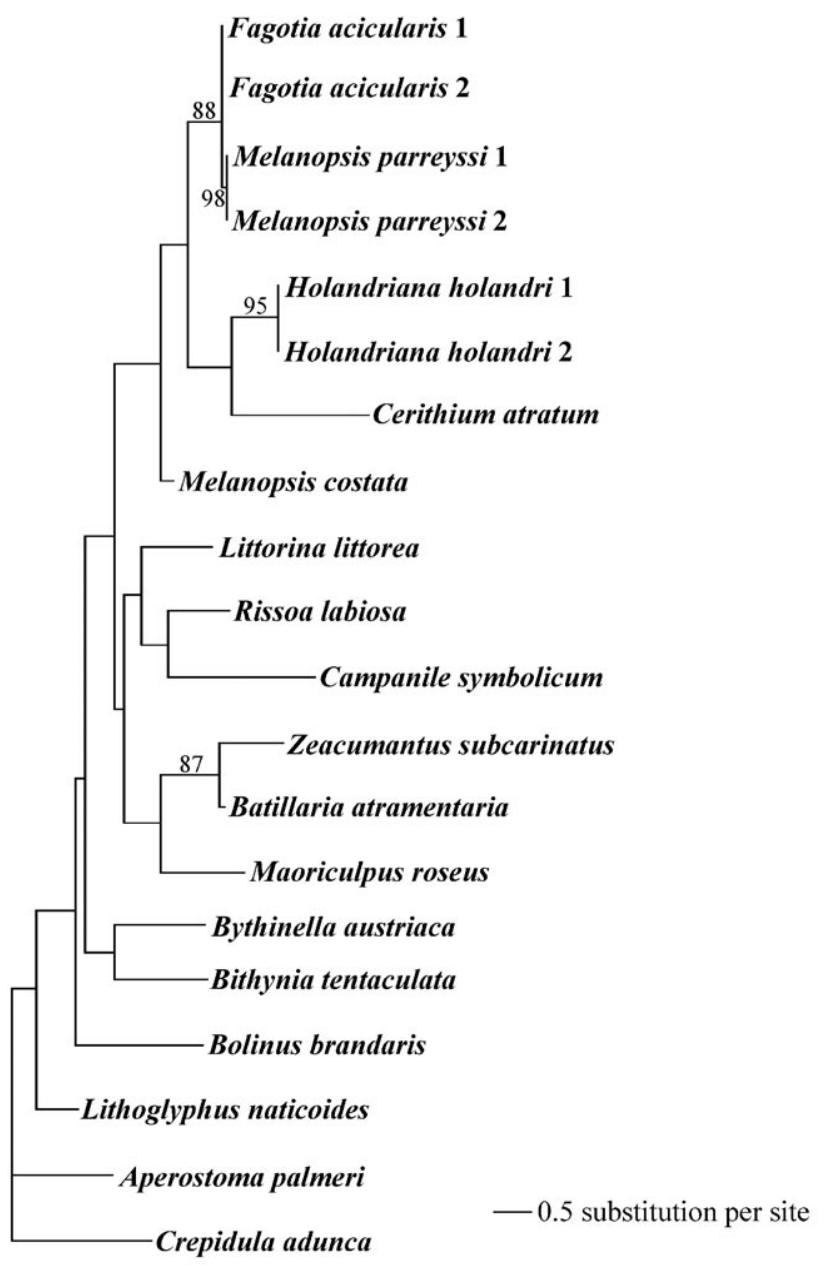

Fig. 2. Maximum likelihood phylogram for COI (see text for details). Bootstrap support indicated (10,000 replicates) when $>50 \%$

ulvae as outgroup, with the above model with no molecular clock had Ln likelihood $=-2137.6527$, and with the molecular clock enforced Ln likelihood = 2142.5857, $\Delta=9.8660, \mathrm{DF}=7, \mathrm{p}>0.1963$, thus the molecular clock hypothesis was not rejected. Tajima's test with Peringia ulvae as outgroup calculated the probabilities: $\mathrm{P}=0.38832$ for Fagotia acicularis and Holandriana holandri, $\mathrm{P}=0.66982$ for $F$. acicularis and Melanopsis parreyssii, and $\mathrm{P}=0.50759$ for $H$. holandri and $M$. parreyssii. With Salenthydrobia ferrerii as outgroup the probabilities were: $\mathrm{P}=0.59192$ for $F$. acicularis and $H$. holandri, $\mathrm{P}=0.25135$ for $F$. acicularis and $M$. parreyssii, and $\mathrm{P}=1.00000$ for $H$. holandri and M. parreyssii. Thus, Tajima's test also did not reject the molecular clock hypothesis.

The Maximum Composite Likelihood distances $(\Delta)$, with their standard error bootstrap estimates (Table 2), and the time of divergence 5.96 Mya, correcting WILKE's (2003) calibration (see the Discussion) were used to estimate the time of divergence. The estimated time was 2.53 \pm 0.56 Mya for Melanopsis parreyssii and Fagotia acicularis; $9.49 \pm 1.67$ Mya for M. parreyssii and Holandriana holandri; $10.71 \pm 1.88$ Mya for $F$. acicularis and $H$. holandri.

Table 2. Distances used for estimation of the time of divergence: below diagonal Maximum Composite Likelihood distances

$(\Gamma)$ with standard errors, above diagonal K2P distances with standard errors (10,000 bootstrap replicates)

\begin{tabular}{|c|c|c|c|c|c|c|c|c|}
\hline & 1 & 2 & 3 & 4 & 5 & 6 & 7 & 8 \\
\hline F. acicularis 1 & ** & $0.0048 \pm 0.0027$ & $.2001+0.0204$ & $0.2081 \pm 0.0$ & $0.0519 \pm 0.0093$ & $0.0519 \pm 0.0094$ & $0.2314 \pm 0.0220$ & \\
\hline F. acicularis 2 & $0.0048 \pm 0.0027$ & $* * * * * * \pm * * * * * *$ & $0.2041 \pm 0.0202$ & $0.2041 \pm 0.0202$ & $0.0468 \pm 0.0089$ & $0.0468 \pm 0.0090$ & $0.2250 \pm 0.0217$ & $0.2317 \pm 0.0224$ \\
\hline H. holandri 1 & $0.2100 \pm 0.0364$ & $0.2051 \pm 0.0354$ & $* * * * * \pm * * * * * *$ & $0.0000 \pm 0.0000$ & $0.2060 \pm 0.0203$ & $0.2017 \pm 0.0202$ & $0.2503 \pm 0.0237$ & $0.2427 \pm 0.0228$ \\
\hline H. holandri 2 & $0.2100 \pm 0.0364$ & $0.2051 \pm 0.0354$ & $0.0000 \pm 0.0000$ & $* * * * * \pm * * * * *$ & $0.2060 \pm 0.0203$ & $0.2017 \pm 0.0202$ & $0.2503 \pm 0.0237$ & $0.2427 \pm 0.0228$ \\
\hline M. parreyssii 1 & $0.0516 \pm 0.0108$ & $0.0464 \pm 0.0102$ & $0.2078 \pm 0.0364$ & $0.2078 \pm 0.0364$ & $* * * * * * * * * * * *$ & $0.0032 \pm 0.0022$ & $0.2358 \pm 0.0225$ & $0.2430 \pm 0.0229$ \\
\hline M. parreyssii 2 & $0.0516 \pm 0.0107$ & $0.0463 \pm 0.0101$ & $0.2035 \pm 0.0361$ & $0.2035 \pm 0.0361$ & $0.0032 \pm 0.0022$ & $* . * * * * \pm * . * * * *$ & $0.2383 \pm 0.0227$ & $0.2452 \pm 0.0230$ \\
\hline P. ulvae & $0.2358 \pm 0.0427$ & $0.2285 \pm 0.0425$ & $0.2528 \pm 0.0439$ & $0.2528 \pm 0.0439$ & $0.2403 \pm 0.0398$ & $0.2421 \pm 0.0415$ & $* * * * * *_{ \pm} * * * * *$ & $0.1195 \pm 0.0156$ \\
\hline S. ferrerii & $0.2430 \pm 0.0430$ & $0.2356 \pm 0.0413$ & $0.2469 \pm 0.0428$ & $0.2469 \pm 0.0428$ & $0.2472 \pm 0.0441$ & $0.2496 \pm 0.0443$ & $0.1155 \pm 0.0205$ & $* * * * * * * * * * * *$ \\
\hline
\end{tabular}




\section{DISCUSSION}

The 18S tree confirmed the monophyly of both the Melanopsidae and Cerithioidea, questioned by LYDEARD et al. (2002). It may be due to the set of taxa used, but no other $18 \mathrm{~S}$ cerithioid sequences were available. On the other hand, the COI tree confirmed the monophyly of neither Melanopsidae nor Cerithioidea. It has to be noted, however, that this tree did not confirm the monophyly of the Rissooidea either. The question of the monophyly of the Melanopsidae remains open. The position of the Iraqui Melanopsis costata, far from the three European melanopsid species, suggests that the inclusion of a taxon from outside Europe may have resulted in a definite rejection of the monophyly of the Melanopsidae.

The distances for the COI, which are much more appropriate to genus-level phylogenies than the very conservative 18S, suggest that Melanopsis parreyssii and Fagotia acicularis are congeneric, and both belong to the genus Melanopsis (Philippi, 1847). On the other hand, Melanopsis costata from Iraq cannot be congeneric with $M$. parreyssii. Holandriana is markedly different, thus confirming the classification of THIELE (1929), who placed it in a distinct subfamily.

Despite all precautions concerning the molecular clock concept and scaling (HILLIS et al. 1996, AVISE 2000, NeI \& KUMAR 2000, POSADA 2003), there are many instances of its usage in prosobranch snails (WILKE 2003, 2004, HAASE et al. 2007, FALNIOWSKI et al. 2007, 2008). The calibration point estimated for the Rissooidea (Hydrobiidae) need not be applicable to the Melanopsidae, but there are no other data available. The distances considered are within a range that most probably is not yet affected by saturation (WILKE et al. 2001), but with one point calibration it is not possible to obtain reasonable estimates of confidence intervals (HILLIS et al. 1996).

HAASE et al. (2007) pointed out another problem concerning calibration. 5.33 Mya is the time of the end of the Messinian Salinity Crisis (Pliocene Flooding). In fact, the isolation of the Atlantic Peringia from the Mediterranean Salenthydrobia must have begun earlier: when the Mediterranean Basin started to separate from the Atlantic, 5.96 Mya (KRIJGSMAN et al. 1999, FALNIOWSKI et al. 2007, 2008). 5.33 Мya Salenthydrobia became isolated in a brackishwater habitat from the other Hydrobia Hartmann, 1821 in the Mediterranean, but its isolation from the Atlantic Peringia Paladilhe, 1874 had begun earlier. Thus we used 5.96 Mya as the point of calibration.

The Recent ranges of the studied European melanopsid species overlap. Melanopsis parreyssii inhabits thermal springs and brooks in Transylvania and Budapest (GLÖER 2002). Its distribution, narrower than in the Pliocene, shows a relic character (GROSSU 1986). Fagotia acicularis inhabits springs and running waters from the Black Sea coast to the Hungarian part of the Danube system. It occurs in the lower part of the river Nitra (Slovakia) and at isolated localities in Austria (thermal springs in Villach and Vöslau: GLÖER 2002). This is a Pontic species (LOŽEK 1956) known from the Pleistocene of the Elbe-Saale Mountains, Turing, Harz and Hungary. In the Holocene it reached the Dnepr system. Holandriana holandii is a southeast Alpine element (GLÖER 2002) inhabiting lakes and rivers. It is known from a few localities in Austria, but its main range extends from Dalmatia to Montenegro, Albania and Romania.

Before 3 Mya, in Europe there was a sharp decrease in temperature and in precipitation. Later, the temperature and humidity rose only to be followed by several alternate cold and warm periods, after which, about 2.5 Mya, the glacial period in Europe began (STANLEY 1999) predating the Pleistocene. At that time the subtropical vegetation definitively disappeared from Europe. The estimated divergence time between the Melanopsis parreyssii and Fagotia acicularis - 2.53 \pm 0.56 Mya - clearly coincides with the beginning of the glacial period. The ancestors of the two species probably found shelter in separate glacial refugia. The occurrence of Melanopsis parreyssii in thermal springs may suggest that it survived the glaciations in hot thermal waters, which were quite common during the Pleistocene in the present territory of Romania.

Lake Pannon existed from approximately 12 to 4 Mya, situated in the Pannonian basin of the Central-East Europe. It was formed by isolation from the sea about 12 Mya, when the newly emerging Carpathian mountain chain cut off the Central European Pannonian basin from the South-East European inland sea, the Paratethys (RÖGL 1998, 1999). Its average salinity was approximately 10-12\%o (GEARY et al. 2000). Among its gastropods the Hydrobiidae (more than 180 species described so far) and Melanopsidae (more than 100 species) dominated. It seems that such parallel radiation of the two families was unique to Lake Pannon: in other big, long-lasting lakes there was a radiation of either Hydrobiidae or Melanopsidae. According to HARZHAUSER \& MANDIC (2008), the main radiation of the Melanopsidae in Lake Pannon took place between 10 and 8 Mya.

The estimated time of divergence between the

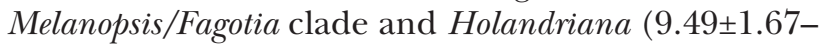
$10.71 \pm 1.88$ Mya) coincides with the time of the main melanopsid radiation in the lake. Considering the Recent ranges of the taxa, it can be assumed that the ancestor of Holandriana inhabited the south or south-west part of the lake, while the ancestor of the Melanopsis/Fagotia clade inhabited its north-eastern part. 


\section{ACKNOWLEDGEMENTS}

The study was supported by the BW grant of the Institute of Zoology, Jagiellonian University. Dr IOAN
SIRBU and Ms MONICA SIRBU helped with the field work in Romania, and Dr MURTADA ALMALIKY kindly provided specimens of Melanopsis costata from Iraq.

\section{REFERENCES}

AviSE J. C. 2000. Phylogeography. The history and formation of species. Harvard University Press, Cambridge, Massachusetts and London, England.

BIELER R. 1998. Non-marine Cerithioidea - Recent work on Thiaridae and Melanopsidae. Veliger 41: 371-372.

Colgan D. J., Ponder W. F., Beacham E., Macaranas J. M. 2003. Molecular phylogenetic studies on Gastropoda based on six gene segments representing coding or non-coding and mitochondrial or nuclear DNA. Moll. Res. 23: 123-148.

Colgan D. J., Ponder W. F., Beacham E., Macaranas J. M. 2007. Molecular phylogenetics of Caenogastropoda (Gastropoda: Mollusca). Mol. Phyl. Evol. 42: 717-737.

COLLIN R. 2003. The utility of morphological characters in gastropod phylogenetics: an example from the Calyptraeidae. Biol. J. Linn. Soc. 78: 541-593.

Davis G. M., Wilke T., SPOlskY C., QIU C.-P., QIU D.-C., XIA M.-Y., ZHANG Y., RosenberG G. 1998. Cytochrome oxidase I-based phylogenetic relationships among the Pomatiopsidae, Hydrobiidae, Rissoidae and Truncatellidae (Gastropoda: Caenogastropoda: Rissoacea). Malacologia 40: 251-266.

FALNIOWSKI A. 2003. Metody numeryczne w taksonomii. Wydawnictwo Uniwersytetu Jagiellońskiego, Kraków.

FAlNiOWSki A., Heller J., MAZAN-MamCZARZ K., SZAROWSKA M. 2002a. Genetic structure of the closely related species of Melanopsis (Gastropoda: Cerithiacea) in Israel. J. Zool. Syst. Evol. Res. 40: 92-104.

FALniowski A., Heller J., SZAROWSKA M., MAZAN-MAMCZARZ K. 2002b. Allozymic taxonomy within the genus Melanopsis (Gastropoda: Cerithiacea) in Israel: a case in which slight differences are congruent. Malacologia 44: 307-324.

FAlNiOWSki A., SZarowska M., GrZMIL P. 2007. Daphniola Radoman, 1973 (Gastropoda: Hydrobiidae): shell biometry, mtDNA, and the Pliocene flooding. J. Nat. Hist. 41: 2301-2311.

FAlniowski A., Szarowska M., Sirbu I., Hillebrand A., BACIU M. 2008. Heleobia dobrogica (Grossu \& Negrea, 1989) (Gastropoda: Rissooidea: Cochliopidae) and the estimated time of its isolation in a continental analogue of hydrothermal vents. Moll. Res. 28: 165-170.

Folmer O., Black M., Hoeh W., LutZ R. A., VRIJENHOEK R.C. 1994. DNA primers for amplification of mitochondrial cytochrome c oxidase subunit I from diverse metazoan invertebrates. Mol. Mar. Biol. Biotechnol. 3: 294-299.

GAUT B. S., LEWIS P. O. 1995. Success of maximum likelihood phylogeny inference in the four-taxon case. Mol. Biol. Evol. 12: 152-162.
Geary D. H., Magyar I., Müller P. 2000. Ancient Lake Pannon and its Endemic Molluscan Fauna (Central Europe; Mio-Pliocene). Adv. Ecol. Res. 31: 463-482.

Giribet G., OKusu A., Lindgren A. R., Huff S. W., SCHRÖDL M., NiSHIGUCHI M. K. 2006. Evidence for a clade composed of molluscs with serially repeated structures: Monoplacophora are related to chitons. Proc. Nat. Acad. Sci. U.S.A. 103: 7723-7728.

GLÖER P. 2002. Die Süsswassergastropoden Nord- und Mitteleuropas, Bestimmungsschlüssel, Lebensweise, Verbreitung. Die Tierwelt Deutschlands 73, ConchBooks, Hackenheim.

Grossu A.V. 1986. Gastropoda Romaniae, vol. 1; I. Caracterele generale, istoricul şi biologia gastropodelor; II. Subclasa Prosobranchia şi Opistobranchia. Ed. Litera, București.

HaAse M., Marshall B., Hogg I. 2007. Disentangling causes of disjunction on the South Island of New Zealand: the Alpine fault hypothesis of vicariance revisited. Biol. J. Linn. Soc. 91, 361-374.

HALL T. A. 1999. BioEdit: a user-friendly biological sequence alignment editor and analysis program for Windows 95/98/NT. Nucleic Acids Symp. Ser. 41: 95-98.

HaRASEWYCH M. G., AdAMkEWICZ S. L., Blade J. A., SAUdeK D., SpRigGS T., BUlt C. J. 1997. Phylogeny and relationships of pleurotomariid gastropods (Mollusca: Gastropoda) and assessment based on partial 18S rDNA and cytochrome c oxidase I sequences. Mol. Mar. Biol. Biotechnol. 6: 1-20.

Harasewych M. G., AdAmkewicz S. L., Plassmeyer M., GILLEVET P. M. 1998. Phylogenetic relationships of the lower Caenogastropoda (Mollusca, Gastropoda, Architaenioglossa, Campaniloidea, Cerithioidea) as determined by partial $18 \mathrm{~S}$ rDNA sequences. Zool. Scripta 27: 361-372.

HARZHAUSER M., MANDIC O. 2008. Neogene lake systems of Central and South-Eastern Europe: Faunal diversity, gradients and interrelations. Palaeo 260: 417-434.

HAUSDORF B., RÖPSTORF P., RIEDEL F. 2003. Relationships and origin of endemic Lake Baikal gastropods (Ceanogastropoda: Rissooidea) based on mitochondrial DNA sequences. Mol. Phyl. Evol. 26: 435-443.

Hillis D. M., MABle B. K., MORITZ C. 1996. Applications of molecular systematics: The state of the field and a look to the future. In: Hillis D. M., MORITZ C., MABLE B. K. (eds). Molecular Systematics. Second edition, Sinauer Associates, Inc., Sunderland, Massachusetts, pp. 515-543.

Hodgson A. N., Heller J. 1997. Spermatozoon structure and spermiogenesis in four species of Melanopsis (Gastropoda, Prosobranchia, Cerithioidea) from Israel. Invertebr. Reprod. Dev. 37: 185-200. 
HOUBRICK R. S. 1988. Cerithioidean phylogeny. Malac. Rev., Suppl. 4: 88-128.

KIMURA M. 1980. A simple method for estimating evolutionary rate of base substitutions through comparative studies of nucleotide sequences. J. Mol. Evol. 16: 111-120.

KrijgSman W., Hilgen F. J., RAFFi I., Sierro F. J., Wilson D. S. 1999. Chronology, causes and progression of the Messinian salinity crisis. Nature 400: 652-655.

LOŽEK V. 1956. Klič československých mekky̌šů. Vydavatelstwo Slovenskej Akademie Vied, Bratislava.

LyDEARD Ch., HolzNAGEl W. E., Glaubrecht M., PONDER W. F. 2002. Molecular phylogeny of a circum-global, diverse gastropod superfamily (Cerithioidea: Mollusca: Caenogastropoda): pushing the deepest phylogenetic limits of mitochondrial LSU rDNA sequences. Mol. Phyl. Evol. 22: 399-406.

MADDISON D. R., MADDISON W. P. 2002. MACCLADE 4.05. Sinauer Associates, Inc. Publishers, Sunderland, Massachusetts.

Miura O., TORChin M. E., Kuris A. M., HeChinger R. F., CHIBA S. 2006. Introduced cryptic species of parasites exhibit different invasion pathways. Proc. Nat. Acad. Sci. U.S.A. 103: 19818-19823.

NEI M. 1987. Molecular Evolutionary Genetics. Columbia University Press, New York.

NEI M. 1996. Phylogenetic analysis in molecular evolutionary genetics. Ann. Rev. Genetics 30: 371-403.

NeI M., KUmAR S. 2000. Molecular Evolution and Phylogenetics. Oxford University Press, Oxford UK and New York.

Nei M., Kumar S., TAKahashi K. 1998. The optimization principle in phylogenetic analysis tends to give incorrect topologies when the number of nucleotides or amino acids used is small. Proc. Nat. Acad. Sci. U.S.A. 76: 5269-5273.

PALUmbI S. R. 1996. Nucleic Acids II: The Polymerase Chain Reaction. In: Hillis D. M., MORITZ C., MABLE B. K. (eds). Molecular Systematics. Second Edition. Sinauer Associates, Inc., Sunderland, Massachusetts, pp. 205-247.

PONDER W. F., WARÉN A. 1988. Appendix: Classification of the Caenogastropoda and Heterostropha - a list of the family-group names and higher taxa. Malacol. Rev., Suppl. 4: $288-326$.

PosAdA D. 2003. Selecting models of evolution. In: SALEMI M., VANDAMme A.-M. (eds). The Phylogenetic Handbook. A Practical Approach to DNA and Protein Phylogeny. Cambridge University Press, Cambridge, UK, pp. 256-282.

POSADA D., BUCKLEY T. R. 2004. Model selection and model averaging in phylogenetics: Advantages of akaike information criterion and Bayesian approaches over likelihood ratio tests. Syst. Biol. 53: 793-808.

PosadA D., Crandall K. A. 1998. Modeltest: testing the model of DNA substitution. Bioinformatics 14: 817-818.

RöGL F. 1998. Palaeogeographic Considerations for Mediterranean and Paratethys Seaways (Oligocene to Miocene). Ann. Nathist. Mus. Wien 99A: 279-310.
RÖGL F. 1999. Mediterranean and Paratethys. Facts and hypotheses of an Oligocene to Miocene paleogeography (short overview). Geologica Carpathica 50: 339-349.

SPOLSKY C., DAVIS G. M., ZHANG Y. 1996. Sequencing methodology and phylogenetic analysis: cytochrome $\mathrm{b}$ gene sequence reveals significant diversity in Chinese populations of Oncomelania (Gastropoda: Pomatiopsidae). Malacologia 38: 213-221.

STANLEY S. M. 1999. Earth System History. W. H. Freeman \& Co., New York - Basingstoke.

SWOFFORD D. L. 2002. PAUP*. Phylogenetic analysis using parsimony (* and other methods). Version 4. Sinauer Associates Inc., Sunderland, Massachusetts.

SWOFFORd D. L., Olsen G. J., WAdDell P. J., Hillis D. M. 1996. Phylogenetic inference. In: HILlis D. M., MORITZ C., MABLE B. K. (eds). Molecular Systematics. Second edition. Sinauer Associates, Inc., Sunderland, Massachusetts, pp. 407-514.

SZAROWSKA M. 2006. Molecular phylogeny, systematics and morphological character evolution in the Balkan Rissooidea (Caenogastropoda). Folia Malacol. 14: 99-168.

SZAROWSKA M., FALNIOWSKI A., RIEDEL F., Wilke T. 2005. Phylogenetic relationships of the subfamily Pyrgulinae (Gastropoda: Caenogastropoda: Hydrobiidae) with emphasis on the genus Dianella Gude, 1913. Zootaxa 891: $1-32$.

TAJIMA F. 1993. Simple methods for testing molecular clock hypothesis. Genetics 135: 599-607.

TAKAHASHI K., NEI M. 2000. Efficiencies of fast algorithms of phylogenetic inference under the criteria of maximum parsimony, minimum evolution and maximum likelihood when a large number of sequences are used. Mol. Biol. Evol. 17: 1251-1258.

TAMura K., Dudley J., NeI M., Kumar S. 2007. MEGA4: Molecular evolutionary genetics analysis (MEGA) software version 4.0. Mol. Biol. Evol. 24: 1596-1599.

THIELE J. 1929. Handbuch der systematischen Weichtierkunde. Erster Teil. Verlag von Gustav Fischer, Jena.

Thompson J. D., Gibson T. J., Plewniak F., Jeanmougin F., HiGGINS D. G. 1997. The ClustalX windows interface: flexible strategies for multiple sequence alignment aided by quality analysis tools. Nucleic Acids Res. 24: 4876-4882.

WiLkE T. 2003. Salenthydrobia gen. nov. (Rissooidea: Hydrobiidae): a potential relict of the Messinian salinity crisis. Zool. J. Linn. Soc. 137: 319-336.

Wilke T. 2004. How dependable is a non-local molecular clock? A reply to Hausdorf et al. (2003). Mol. Phyl. Evol. 30: 835-840.

Wilke T., DaVis G. M., FALniowski A., GiUsti F., BODON M., SZAROWSKA M. 2001. Molecular systematics of hydrobiidae (Mollusca: Gastropoda: Rissooidea): testing monophyly and phylogenetic relationships. Proc. Acad. Nat. Sci. Philad. 151: 1-21.

WILLIAMS S.T., REID D.G. 2004. Speciation and diversity on tropical rocky shores: a global phylogeny of snails of the genus Echinolittorina. Evolution 58: 2227-2251. 
WiNNEPENNINCKX B., STEINER G., BACKELJAU T., De WACHTER R. 1998. Details of gastropod phylogeny inferred from 18S rRNA sequences. Mol. Phyl. Evol. 9: $55-63$.

YANG Z. 1997. How often do wrong models produce better phylogenies? Mol. Biol. Evol. 14: 105-108.
YANG Z., GOLDMAN N., FRIDAY A. 1995. Maximum likelihood trees from DNA sequences: A peculiar statistical estimation problem. Syst. Biol. 44: 384-399.

Received: April 25th, 2009

Accepted: May 20th, 2009 